\title{
PENEGAKAN HUKUM TINDAK PIDANA POLITIK UANG PEMILIHAN UMUM LEGISLATIF PADA MASA KAMPANYE DI KABUPATEN SERANG
}

\author{
Asnawi \\ Dosen Sekolah Tinggi Ilmu Ekonomi Bina Bangsa \\ E-mail:srgasnawi@gmail.com
}

\begin{abstract}
ABSTRAK
Pemilihan umum tahun 2014 diselenggarakan dengan tujuan untuk memilih wakil rakyat yang merupakan perwujudan demokrasi sebagai kedaulatan rakyat. Penelitian ini bertujuan untuk mengetahui ada tidaknya pelanggaran tindak pidana politik uang pemilihan umum legislatif pada masa kampanye di Kabupaten Serang menurut UndangUndang Nomor 8 Tahun 2012 tentang Pemilihan Umum Anggota DPR, DPD, dan DPRD. Penelitian ini dilakukan dengan menggunakan metode pendekatan yuridis empiris yaitu melakukan penelitian secara langsung di panitia pengawas Pemilu Kabupaten Serang berdasarkan hasil penelitian pelanggaran yang dilaporkan kepanitiaan pengawas Pemilu banyak terjadi adalah pada saat kampanye yang melibatkan anak-anak di bawah umur dan politik uang (money politics). Namun pada kenyataannya pelanggaran yang paling banyak adalah pelanggaran politik uang. Modus pelanggaran Pemilu politik uang yang dilakukan calon anggota legislatif Kabupaten Serang adalah (1) praktik politik uang secara langsung berupa uang tunai atau barang yang dibagi-bagikan secara langsung oleh calon anggota legislatif maupun tim sukses; (2) praktik politik uang secara tidak langsung membagi-bagikan sembako seperti beras, mie, minyak sayur, telor dan lain-lainnya); menjanjikan sesuatu, memberikan dana bantuan secara kelompok maupun individu. Identifikasi masalah sebagai berikut 1) Bagaimana penegakan hukum terhadap tindak pidana Pemilu politik uang yang memenuhi aspek kepastian hukum? 2) Bagaimana jenis dan bentuk perbuatan yang dapat dikualifikasi sebagai tindak pidana politik uang pada masa kampanye? Faktanya penanganan kasus politik uang Kabupaten Serang sulit untuk dibuktikan karena kurang cukup bukti, kendala-kendala pelanggaran Pemilu politik uang dalam penegakan hukum di Kabupaten Serang, Pengawas Pemilu Kabupaten Serang kesulitan menemukan buktibukti pelanggaran Pemilu politik uang dan kurangnya partisipasi dari masyarakat, perlunya pendidikan politik, dan aparat penegakan hukum harus berani dan netralitas.
\end{abstract}

Kata kunci: Pemilihan Umum, Politik Uang, Tindak Pidana, Penegakan Hukum.

\section{ABSTRACT}

Regarding to the democracy as the people's sovereignty, the general election of 2014 was held by the aim to select a representative. The aim of this study is to determine whether there is criminal offense of money politics in Serang district during the legislative electoral campaign according to the regulation no. 8 of 2012 on the General Election of DPR, DPD and DPRD. This research was conducted by using juridical empirical approach directly to the committee electoral supervisor of Serang District as the result of violations that was reported by the committee electoral supervisors during campaigns, involving children under the age and money politics, but in fact most of the 
violations are money politics. Modes of money politics violation that committed by legislative candidates in Serang are (1) Direct money politics in the form of cash or stuffs by legislative candidates or successful teams; (2) Indirect money politics in form of distributing foods such as rice, noodles, vegetable oil, eggs and others; promising grants for a group or individual. The identification of the problem are 1) How the law enforcement against criminal acts of money politics fulfills the legal certainty? 2) What types and forms of acts that can be qualified as criminalization of money politics during the campaign? In fact, to prove money politics cases in Serang is difficult, because of insufficient evidence, political constraints of money politics violations in general election of law enforcement in Serang, electoral supervisor having trouble in finding evidence of violations of electoral money politics and lack of attention from environment, the need for political education, and encouragement and fair of law enforcement officers.

Keywords: General Election, Money Politics, Criminalism, Law Enforcement.

\section{PENDAHULUAN}

Pemilihan umum (Pemilu) merupakan perwujudan demokrasi sebagai kedaulatan rakyat dari hasil amandemen Undang-Undang Dasar Negara Republik Indonesia Tahun 1945 menyatakan bahwa kedudukan berada di tangan rakyat dan dilaksanakan menurut Undang-Undang Dasar. Ditegaskan pula bahwa Negara Indonesia adalah Negara hukum. Makna dari "kedudukan di tangan rakyat" adalah bahwa rakyat memiliki kedaulatan, tanggung jawab, hak dan kewajiban untuk secara demokratis memilih pimpinan yang akan membentuk pemerintahan guna mengurus dan melayani seluruh lapisan masyarakat, serta memilih wakil rakyat untuk mengawasi jalannya pemerintahan. Perwujudan kedaulatan rakyat dilaksanakan melalui Pemilu secara langsung sebagai sarana bagi rakyat untuk memilih wakilnya yang akan menjalankan fungsi melakukan pengawasan, menyalurkan aspirasi politik rakyat, membuat undang-undang sebagai landasan bagi semua pihak di Negara Kesatuan Republik Indonesia dalam menjalankan fungsi masingmasing, serta merumuskan anggaran pendapatan dan belanja untuk membiayai pelaksanaan fungsi-fungsi tersebut.

Berdasarkan pemikiran di atas menunjukkan bahwa aspek utama dalam Pemilu adalah unsur penyelenggara dapat mematuhi hukum dalam penyelenggaraan Pemilu, komitmen yang diharapkan dari rakyat adalah penyelenggaraan Pemilu yang mendapatkan legitimasi dan legalitas. 
Pemilihan umum yang berhasil bisa dicapai hanya jika dalam pembentukan undang-undang Pemilu memperhatikan berbagai aspek, antara lain jumlah maksimal anggota DPR meskipun ada tambahan penduduk. Keseimbangan antara perwakilan, penyederhanaan jumlah partai, keterpaduan kekuatan politik di DPR, pemilihan yang mendekatkan wakil dengan rakyat pemilih, mendorong keanggotaan yang bermutu dan berwawasan luas, optimalisasi fungsi partai dalam melakukan pendidikan politik terhadap kadernya, mencegah terjadinya pemusatan kekuatan politik pada satu partai, dan mencegah proses sentrifugal atau fragmentasi antar kekuatan politik, menjamin Pemilu yang jujur, adil, terbuka, tertib dan terhindar dan segala macam bentuk tekanan atau cara-cara lain yang bertentangan dengan norma hukum atau kesusilaan, dan menjamin hak-hak perwakilan minoritas yang tidak dapat diraih melalui Pemilu. Dengan kata lain Pemilu dapat dikatakan sukses bila ditinjau dari segi hasil ialah jika Pemilu yang dilaksanakan dapat menghasilkan wakil-wakil rakyat dan pemimpin Negara, yang mampu mewujudkan cita-cita nasional, sebagaimana tercantum dalam pembukaan UUD
Negara Republik Indonesia Tahun $1945 .^{1}$

Pemilu yang diselenggarakan memiliki manfaat yang sangat besar bagi bangsa Indonesia diantara manfaat tersebut adalah Pemilu merupakan implementasi perwujudan kedaulatan rakyat. Asumsi demokrasi adalah kedaulatan terletak di tangan rakyat, karena rakyat yang berdaulat itu tidak bisa memerintah secara langsung maka melalui Pemilu rakyat dapat menentukan wakil-wakilnya dan para wakil rakyat tersebut akan menentukan siapa yang akan memegang tampuk pemerintahan.

Dalam Pemilu tahun 2014 bermaksud memaparkan norma hukum yang berkaitan dengan penegakan hukum tidak pidana dalam pemilihan umum pada umumnya, khususnya tidak pidana politik uang (money politics) dalam Pemilu legislatif ditingkat daerah. Pemetaannya dilakukan dengan menghubungkan kenyataan empiris bagaimana penegakan hukum dilakukan dan seberapa efektifnya, untuk memperkuat pembahasan, maka dalam konteks ini dikaitkan dengan praktik penyelenggaraan pemilihan umum legislatif (DPR, DPD, dan DPRD)

1 Rozali Abdullah, Mewujudkan Pemilu yang Lebih Berkualitas (Pemilu Legislatif), Raja Grafindo Persada, Jakarta, 2009, hlm. 3. 
didaerah menurut Undang-Undang Nomor 8 Tahun 2012 tentang Pemilihan Umum anggota DPR, DPD dan DPRD.

Pidana politik uang (money politics). Sebagai mana diuraikan di atas definisi dimensi kejahatan, pelanggaran, dan kecurangan dalam pemilihan umum tahun 2014 yang dikategorikan tindak pidana Pemilu adalah kejahatan yang dilakukan oleh partai politik atau caleg yang memberikan sesuatu atau uang. paling sering dilakukan di saat masa kampanye berlangsung karena persaingan antara partai politik yang satu dan lain sangat keras untuk mendapat simpati dari masyarakat, tujuannya tak lain agar masyarakat tertarik dan percaya terhadap partai yang memberikan sesuatu barang atau uang, hal yang sama juga dilakukan selain persaingan partai politik juga persaingan yang lebih keras lagi antara calon anggota legislatif, dalam persaingan yang menimbulkan pelanggaran Pemilu karena saling merebut dukungan dari masyarakat untuk memperoleh suara dukungan didaerah pemilihan, persaingan antara calon anggota legislatif satu partai maupun dengan partai lain didaerah pemilihan yang sama untuk merebut dukungan dari masyarakat, untuk memperoleh dukungan tersebut calon anggota legislatif yang mempunyai modal besar membagi-bagikan uang dan barang untuk mendapatkan dukungan dari masyarakat. Tindakan tersebut melanggar aturan-aturan hukum dan tujuan demokrasi di Indonesia. Terutama adalah pelanggaran tindak pidana Pemilu politik uang pada masa kampanye yang diatur dalam Undang-Undang Nomor 8 Tahun 2012 tentang Pemilihan Umum anggota DPR, DPD dan DPRD dan Kitab Undang-Undang Hukum Pidana (KUHP).

Berdasarkan fakta yang ada pelanggaran politik uang (money politics) itu ada masyarakat tidak mau melaporkan kepada Panwas sebagai aparat penegak hukum. Kelemahan sistem Pemilu yang memberikan peluang pada calon anggota legislatif bermain politik uang karena kelemahan dalam pengawasan. Pelanggaran Pasal 301 ayat (1) Undang-Undang Nomor 8 Tahun 2012 yang banyak dilakukan calon anggota legislatif pada masa kampanye adalah politik uang (money politics) yang mayoritas pada masa kampanye membagi-bagikan uang maupun barang pada calon pemilih. Untuk mempengaruhi keputusan masyarakat agar memilih caleg tersebut dalam Pemilu, praktik politik uang merupakan praktik 
yang sangat bertentangan dengan nilai demokrasi. Praktik politik uang ini sungguh misterius karena sulitnya mencari data untuk membuktikan sumber praktik tersebut karena yang menerima calon pemilih menunggu pemberian dari caleg atau tim suksesnya apa lagi sampai melaporkan ke pihakpihak yang berwenang panwas, namun ironisnya praktik politik uang ini sudah menjadi kebiasaan dan rahasia umum di masyarakat. Real-nya sistem demokrasi Pemilu di Indonesia masih harus banyak perbaikan, masih jauh dari harapan sistem Pemilu yang demokratis jujur dan adil. Hambatan terbesar dalam pelaksanaan Pemilu yaitu masih tertanamnya budaya politik uang di masyarakat. Elitelit politik menggunakan kekuasaan dan uang untuk melakukan pembodohan dan kebohongan terhadap masyarakat dalam mencapai kemenangan politik. Banyak muncul kasus-kasus masalah dalam pemilihan calon anggota legislatif yang dibawa dan diputuskan kasusnya melalui lembaga peradilan Mahkamah Konstitusi (MK) karena pelanggaran nilai demokrasi dan tujuan pemilihan calon anggota legislatif secara jujur dan adil masih banyak hambatan dan pelanggaran. Hal itu membuktikan betapa terpuruknya sistem Pemilu di
Indonesia yang memerlukan penanganan yang lebih serius. Masyarakat yang kondisi ekonominya masih banyak kekurangan dan kesulitan, pengetahuan pendidikan politiknya masih awam akan menjadi sasaran empuk para pelaku praktik politik uang (money politics).

Secara yuridis formal ketentuan yang sering dianggap sebagai norma politik uang ditentukan dalam UndangUndang Nomor 8 Tahun 2012 Tentang Pemilihan umum anggota DPR, DPD dan DPRD. Pasal 301 ayat 1, ayat 2 dan ayat 3 .

(1) "Menyatakan setiap pelaksana kampanye Pemilu yang dengan sengaja menjanjikan atau memberikan uang atau materi lainnya sebagai imbalan kepada peserta kampanye Pemilu secara langsung ataupun tidak langsung sebagaimana dimaksud dalam pasal 89 dipidana dengan pidana penjara paling lama 2 (dua) tahun dan denda paling banyak Rp24.000.000,- (dua puluh empat juta rupiah).

(2) Setiap pelaksana, peserta, dan/atau petugas kampanye Pemilu yang dengan sengaja pada masa tenang menjanjikan atau memberikan imbalan uang atau materi lainnya kepada pemilih secara langsung ataupun tidak langsung sebagaimana dimaksud dalam pasal 48 dipidana dengan pidana penjara paling lama 4 (empat) tahun dan denda paling banyak Rp48.000.000,- (empat puluh delapan juta rupiah). 
(3) Setiap orang yang dengan sengaja pada hari pemungutan suara menjanjikan atau memberikan uang atau materi lainnya kepada pemilih untuk tidak menggunakan hak pilihnya atau memilih peserta Pemilu tertentu dipidana dengan pidana penjara paling lama 3 (tiga) tahun dan denda paling banyak Rp36.000.000,- (tiga puluh enam juta rupiah)".

Dari Pasal 301 tersebut yaitu ayat (1) yang melakukan pelanggaran tindak pidana Pemilu politik uang (money politics), pada masa kampanye yang dengan sengaja melakukan dan memberikan imbalan uang dan materi lainnya dikenakan sangsi pidana berdasarkan pelanggaran yang dilakukan. Pelanggaran tindak pidana politik uang pada masa kampanye berlangsung melanggar aturan undangundang Pemilu Pasal 301 ayat (1) dan aturan yang dibuat oleh KPU.

Berdasarkan data yang diperoleh dari panitia pengawas pemilihan umum Kabupaten Serang pelanggaran Pemilu pada masa kampanye di legislatif Kabupaten Serang pada tahun 2014. Panitia pengawas pemilihan umum mencatat 18 kasus tindak pidana Pemilu pada masa kampanye dengan rincian pelanggaran, Kasus dugaan penghilangan data pemilih 1 kasus, Kasus Membagikan barang dana hibah bagi kelembagaan di kecamatan 1 kasus; Kasus Kampanye melibatkan anak di bawah umur 12 kasus; Kasus politik uang (money politics) 1 kasus; Kasus menggunakan sarana ibadah dan sekolah untuk kampanye 2 kasus; Kasus baksos pengobatan gratis 1 kasus; Kasus menggunakan lapangan untuk kampanye tidak punya izin 1 Kasus; dalam pelanggaran ini ada beberapa tersangka calon anggota legislatif caleg yang melakukan. $^{2}$

Banyaknya temuan-temuan di lapangan yang seharusnya di-follow up diteruskan tetapi tidak berjalan karena lemahnya dalam penegakan hukum dengan alasan tidak cukup bukti hanya sanksi administrasi. Dalam pengawasan Pemilu penegak hukum memiliki etos kerja dan moralitas yang rendah seperti mudah menerima suap, menguangkan setiap kasus-kasus pelanggaran, tidak netral dalam pengawasan dan berpihak pada calon yang masih kerabat, ini karena lemahnya aparat penegakan hukum Panwaslu, Kepolisian dan kejaksaan dalam melaksanakan pengawasan.

Dari latar belakang masalah yang telah diuraikan di atas, maka

2 Panitia Pengawas Pemilu Kabupaten Serang, 5 Mei 2015. 
teridentifikasi Masalah sebagai berikut 1) Bagaimana Penegakan Hukum terhadap tindak pidana Pemilu politik uang yang memenuhi aspek kepastian hukum?; 2) Bagaimana jenis dan bentuk perbuatan yang dapat dikualifikasi sebagai tindak pidana politik uang pada masa kampanye?

\section{METODE PENELITIAN}

Metode pendekatan penelitian adalah pendekatan yuridis empiris. Maka untuk menunjang metode tersebut dengan upaya mencari data sekunder yang diperlukan dalam penelitian adalah metode studi atau penelitian kepustakaan, yaitu dengan menginventarisasi data-data sekunder (library research) untuk kemudian dilakukan analisis kualitatif terhadap data-data tersebut. Data yang digunakan dalam penulisan ini adalah data sekunder. Data-data sekunder dalam penulisan ini meliputi: Bahan hukum primer, yaitu bahan-bahan hukum yang mengikat, yang terdiri atas: Kitab Undang-Undang Hukum Pidana (KUHP); Kitab Undang-Undang Hukum Acara Pidana (KUHAP); UndangUndang Nomor 2 Tahun 2008 tentang Partai politik, sebagaimana telah diubah dengan Undang-Undang Nomor 2 Tahun 2011 tentang Perubahan Undang-
Undang 2 Tahun 2008 tentang Partai Politik; Undang-Undang Republik Indonesia Nomor 15 Tahun 2011 tentang Penyelenggara Pemilihan Umum; Undang-Undang Nomor 8 Tahun 2012 tentang Pemilihan umum anggota DPR, DPD dan DPRD. Penelitian dilakukan di Panitia Pengawas Pemilihan Umum Kabupaten Serang Provinsi Banten mulai pada tanggal 29 Juni 2015 sampai dengan 23 Agustus 2015.

\section{HASIL PENELITIAN DAN ANALISIS}

\section{A. Penegakan Hukum terhadap Tindak Pidana Politik Uang yang Memenuhi Aspek Kepastian Hukum}

Kebijakan hukum pidana pada hakikatnya mengandung kebijakan mengatur mengalokasi dan membatasi kekuasaan, baik kekuasaan kewenangan warga masyarakat pada umumnya, untuk bertindak bertingkah laku dalam pergaulan masyarakat maupun kekuasaan atau kewenangan penguasa penegak hukum. Dilihat dari aspek hukum pidana yang demikian, maka dapat dikatakan bahwa masalah dasar hukum pidana terletak di luar bidang 
hukum pidana itu sendiri, yaitu di bidang hukum tata Negara. ${ }^{3}$

Formulasi tindak pidana Pemilu legislatif dalam Undang-Undang Nomor 8 Tahun 2012 tentang Pemilihan Umum Anggota DPR, DPRD, dan DPD maka kebijakan hukum pidana yang telah ditentukan dalam undang-undang tersebut, berdasarkan hasil penelitian, pasal-pasal yang dianalisis dirumuskan memenuhi unsur-unsur pidana dalam hal ini yaitu unsur Tindak Pidana Pemilu, adapun pasal yang memenuhi unsurunsur Tindak Pidana Pemilu dimaksud adalah Pasal 273 sampai dengan Pasal 321. Berdasarkan identifikasi terhadap perumusan Tindak Pidana Pemilu dalam Undang-Undang Nomor 8 Tahun 2012, dapat dikemukakan bahwa dari aspek perbuatan, perilaku dan sanksi pidana terdapat kekhususan.

Kekhususan yang ada pada aspek pembatasan adalah pada UndangUndang Nomor 8 Tahun 2012 Pasal 89, sanksi atas Pelanggaran Larangan Kampanye (Dalam hal terbukti pelaksanaan kampanye Pemilu menjanjikan atau memberikan uang atau materi lainnya sebagai imbalan kepada peserta kampanye Pemilu secara

3 Barda Nawawi Arief, Bunga Rampai Kebijakan Hukum Pidana, Citra Aditya Bakti, Bandung, 2006, hlm. 131. langsung ataupun tidak langsung; a. tidak menggunakan hak pilihnya; $b$. menggunakan hak pilih dengan memilih peserta Pemilu dengan cara tertentu sehingga surat suaranya tidak sah; c. memilih Partai politik peserta Pemilu tertentu; d. memilih calon anggota DPR, DPRD provinsi, DPRD kabupaten/kota tertentu; e. memilih calon DPD tertentu dikenai sanksi sebagaimana diatur dalam undang-undang ini) dan Pasal 301, Kejahatan (Ayat (1) Setiap pelaksanaan kampanye Pemilu yang dengan sengaja menjanjikan atau memberikan uang atau materi lainnya sebagai imbalan kepada peserta kampanye Pemilu secara langsung ataupun tidak langsung sebagaimana dimaksud dalam pasal 89 dipidana dengan pidana penjara paling lama 2 (dua) tahun dengan denda paling banyak Rp24.000.000,00 (dua puluh empat juta rupiah)). Sistem sanksi pidana bersifat komulatif yaitu penggabungan sanksi pidana penjara dan denda sekaligus dikenakan kepada pelaku.

\section{Penerapan Tindak Pidana Pemilu di Kabupaten Serang pada Pemilu} Tahun 2014

Proses penanganan tindak pidana Pemilu di Kabupaten Serang. Pelanggaran Pemilu adalah segala 
bentuk kegiatan yang dilakukan peserta Pemilu dari partai politik, peserta perorangan, pelaksana, peserta, petugas yang ditunjuk oleh peserta Pemilu maupun penyelenggara Pemilu dengan sengaja maupun tidak kegiatan tersebut melanggar peraturan perundangundangan atau peraturan lainnya. Penyelesaian peraturan Pemilu diatur dalam Undang-Undang Nomor 8 tahun 2012 secara umum diselesaikan melalui Bawaslu, Panwaslu sesuai dengan tingkatannya sebagai lembaga yang memiliki kewenangan melakukan pengawasan setiap tahap pelaksanaan Pemilu pengawasan tersebut, Bawaslu, Panwaslu, sesuai tingkatannya, dapat melakukan temuan, menerima laporan, dan melakukan kajian atas laporan dan temuan adanya dugaan pelanggaran dan meneruskan temuan laporan kepada instansi yang berwenang yaitu KPU terhadap pelanggaran administrasi, Penyidik/ Polisi terhadap dugaan tindak pidana pelanggaran Pemilu yang secara administrasi menjadi kewenangan KPU sesuai tingkatannya untuk menyelesaikannya berdasarkan sifatnya sanksi terhadap pelanggaran administrasi adalah sanksi administrasi khusus yang terkait pelanggaran yang dilakukan oleh penyelenggara kepada DKPP, maka
DKPP dapat menggunakan peraturan tentang kode etik.

\section{Pelanggaran Pidana Pemilu dan Penanganannya pada Masa}

\section{Kampanye di Kabupaten Serang}

Berdasarkan hasil temuan dan laporan pelanggaran Pemilu pada masa kampanye Pemilu legislatif di Kabupaten Serang, yang dilaporkan langsung ke Panwaslu Kabupaten Serang maupun yang dilaporkan melalui Panwaslu Kecamatan selama penyelenggaraan masa kampanye Pemilu anggota DPR, DPD, dan DPRD Tahun 2014. Panitia Pengawas Pemilihan umum menerima laporan terdapat 18 (delapan belas) kasus pelanggaran pidana Pemilu, tindak lanjut berbagai pelanggaran pidana Pemilu ditangani oleh Panwaslu Kabupaten Serang. Berikut data mengenai laporan dugaan pelanggaran pidana Pemilu pada masa kampanye Pemilu DPR, DPD dan DPRD tahun 2012 di Kabupaten Serang. Berkaitan dengan pelanggaran pada masa kampanye ada 18 kasus pelanggaran selama masa kampanye di Kabupaten Serang yang melakukan pelanggaran Pemilu politik uang Pasal 301 UndangUndang Nomor 8 Tahun 2012, menyimpulkan bahwa yang melakukan tindak pidana Politik Uang di saat masa 
kampanye ada 5 kasus, namun pada kenyataannya tidak ada kasus yang ditindak lanjuti dengan alasan tidak cukup bukti, hal tersebut di atas maka masih lemahnya dalam penegakan hukum. Yang ditindak lanjuti hanya pelanggaran administrasi, yang ditindak lanjuti direkomendasikan ke KPU diberikan sanksi administrasi oleh KPU, dan direkomendasikan ke KPU untuk diberikan sanksi sesuai dengan peraturan perundang-undangan yang berlaku.

Berdasarkan hasil penelitian di Kabupaten Serang ternyata peran penegak hukum dan peran masyarakat dalam Pemilu legislatif tahun 2014 sangat berpengaruh terhadap jalannya pemilihan umum 2014 dipengaruhi oleh peran masyarakat. Untuk mempengaruhi penegakan hukum dalam penindakan baik unsur pidana maupun unsur administratif tindak pidana Pemilu. Bisa dilihat dari kasus pidana Pemilu di Kabupaten Serang.

Menurut pendapat yang dikemukakan oleh Friedman, bahwa sistem hukum meliputi substansi, struktur, dan budaya hukum, berikut uraian masing-masing elemen, yaitu pertama, substansi hukum adalah aturan, norma dan pola tingkah laku manusia yang berada dalam sistem itu. Pengertian substansi tidak hanya terbatas pada hukum tertulis, tetapi juga hukum yang hidup dan berlaku dalam masyarakat; kedua, struktur hukum adalah yang merupakan institusional ke dalam lintas hukum seperti pengadilan tingkat pertama, banding dan kasasi, serta integrated criminal justice system; ketiga, budaya hukum adalah sikap-sikap dan nilai-nilai yang berhubungan dengan hukum, yang terkait dengan tingkah laku yang berhubungan hukum dengan lembaganya, baik positif maupun negatif. ${ }^{4}$

Faktor penentu kesadaran hukum masyarakat sangat dipengaruhi oleh bekerjanya berbagai faktor dan kekuatan yang ada. Dalam hal ini bahwa tindakan yang akan dilakukan oleh warga masyarakat sebagai respon terhadap peraturan-peraturan hukum sangat tergantung dari isi norma hukum itu sendiri, sanksi-sanksinya, aktivitas para pelaksana hukum serta semua faktorfaktor yuridis yang bekerja atas dirinya. Dengan demikian, harus dapat dipahami setiap undang-undang yang dikeluarkan atau dicabut akan mengalami perubahan, baik melalui perubahan formal maupun melalui cara-cara yang ditempuh birokrasi ketika bertindak. Perubahan itu

\footnotetext{
$4 \quad$ Ibid, hlm. 143.
} 
terjadi disebabkan oleh adanya ketentuan-ketentuan sosial, ekonomi dan sebagainya yang bekerja memberikan impaknya 5 .

Bekerjanya hukum dalam berbagai lingkup dan berbagai faktor kekuatan bahwa proses bekerjanya hukum itu sangat ditentukan oleh beberapa faktor penting, yaitu; pertama, peraturanperaturan hukumnya; kedua, badan pembuat undang-undang; ketiga, badan pelaksana hukum (sanctioning agencies); keempat, masyarakat sebagai sasaran pengaturan (perannya di dalam masyarakat ditentukan oleh apa yang dirumuskan di dalam peraturan); kelima, proses penerapan hukum; keenam, komunikasi hukumnya; ketujuh, kompleks kekuatan sosial politik dan lain-lain yang bekerja atas diri pembuat undang-undang, birokrasi (pelaksana hukum) maupun masyarakat sendiri sebagai pemegang peran; dan kedelapan, proses umpan balik antara semua komponen tersebut.

Sebagai pisau analisis penerapan tindak pidana politik uang pemilihan umum legislatif pada masa kampanye di kabupaten Serang menurut UndangUndang Nomor 8 Tahun 2012 tentang Pemilihan Umum anggota legislatif

\footnotetext{
5 Ibid, hlm. 144.
}

DPR, DPD dan DPRD. Yang menyatakan bahwa, pertama, dalam penegakan hukum, penegak hukum dalam melaksanakan tugas setengahsetengah antara pengawas Pemilu Panwaslu, KPU, penyidik, penuntut dan pemutus perkara tidak sepenuhnya berdasarkan undang-undang. Pendeknya batasan pemutusan perkara pidana Pemilu yang mengakibatkan perkara bisa dipatahkan tanpa proses peradilan (misalnya tidak cukup bukti, daluarsa dan penghentian pemeriksaan oleh penyidik). Kedua, masih dominannya pengaruh Calon anggota legislatif yang berpengaruh dan mempunyai modal besar yang mempengaruhi proses hukum, mengakibatkan kecenderungan Panwaslu dalam pengawasan setengahsetengah, untuk itu perlu petugas penegak hukum yang berani, tegas, dan profesional dalam penegakan pelanggaran Pemilu politik uang pada masa kampanye. Ketiga, masyarakat juga belum terdidik secara sumber daya manusia dalam berpolitik, ini bisa dilihat dengan pemilih peserta Pemilu hanya demi uang (money politics) yang sangat sulit dibuktikan; karena terbentur aturanaturan yang tidak tegas dan jelas. Sementara peserta Pemilu calon anggota legislatif, tidak memahami apa arti 
demokrasi yang sesungguhnya, yaitu suara rakyat yang tertinggi nilainya untuk mewujudkan demokrasi sebagai kedaulatan di tangan rakyat. Masyarakat belum mengerti dan paham tentang hakekat pelanggaran dan tindak pidana Pemilu.

\section{Bentuk Perbuatan yang Dapat}

\section{Dikualifikasi Sebagai Tindak Pidana Politik Uang (Modus Operandi) Masa Kampanye}

\section{a. Money Politics dalam Pemilu}

Praktik dari money politics dalam Pemilu sangat beragam. Diantara bentuk-bentuk kegiatan yang dianggap politik uang antara lain: a) distribusi sumbangan baik berupa barang atau uang kepada para kader partai, tim sukses, golongan atau kelompok tertentu, b) Memberikan sumbangan untuk masyarakat seperti mesjid, musola, madrasah, pondok pesantren, ibu-ibu pengajian untuk memperoleh dukungan dan kepentingan partai politik atau calon anggota Legislatif. c) Membagi-bagikan sembako secara langsung mengunjungi kampungkampung dari rumah ke rumah untuk memperoleh dukungan dan simpati dari masyarakat. d) Pada hari H. Pelaksanaan kampanye membagi-bagikan uang, dan barang-barang lainnya untuk mendapat dukungan simpati dari kader, simpatisan dan masyarakat lainnya. e) Memberikan sumbangan kepada perkumpulan kelompok pemuda karang taruna, seperti memberikan uang, bola voli, kaos tim bola, kaos tim voli, membuat lapangan bulutangkis, dan lain-lain untuk memperoleh dukungan dan kepentingan dari kalangan pemuda.

Dari sisi waktunya, praktik money politics di negara ini dapat dikelompokkan menjadi dua tahapan yakni pra pemungutan. Pada pra pemungutan suara mulai dari seleksi administrasi, masa kampanye, masa tenang dan menjelang pemungutan. Sasarannya adalah para pemilih, terutama mereka yang masih mudah untuk dipengaruhi. Untuk tahap kedua adalah setelah pemungutan.

Demikian eratnya hubungan uang dengan politik, sehingga jika politik uang tetap merajalela niscaya calon anggota legislatif yang potensial melakukan praktik tersebut hanya partai atau calon anggota legislatif yang memiliki dana besar. Berapapun besarnya jumlah dana yang dikeluarkan, keuntungan yang diperoleh tetap akan jauh lebih besar. Sebab pihak yang diuntungkan dalam praktik politik uang 
adalah pihak pemberi caleg, karena dia akan memperoleh dukungan dan kekuasaan politik yang harganya tidak ternilai. Adapun yang dirugikan adalah rakyat. Ketika calon anggota legislatif tersebut berkesempatan terpilih untuk membuat kebijakan, maka ia akan mengambil suatu keuntungan besar dari kebijakan tersebut.

Pendekatan dilakukan baik secara langsung maupun dengan melalui perantara orang ketiga. Pada saat inilah transaksi dilakukan baik dengan memberikan uang kontan ataupun dengan suatu janji atau pemberian atas pemberian. Namun hal yang intinya politik uang adalah bagaimana strategi pemberian uang. Bukan tindakan menyuap dan disuap merupakan perbuatan melanggar hukum, oleh karena itu proses "penyampaian uang" harus dilakukan secara rapi. Namun, yang pasti bagi mereka yang terlibat dalam politik uang, Yaitu dengan cara mendatangi secara langsung rumah ke rumah dengan istilah door to door untuk memberikan uang suap politik uang, hal ini dilakukan untuk semaksimal mungkin menghilangkan jejak. Dan hal ini akan memberikan peluang bagi calon anggota legislatif yang kalah guna membongkar praktik politik uang yang dilakukan oleh calon legislatif timnya dalam memenangkan Pemilu. Dan juga hal ini akan memberikan kesan negatif bahwa calon tersebut melakukan praktik politik uang guna memenangkan pemilihan umum tersebut. Selain itu ternyata pemberian uang tidak pula selalu dilakukan oleh para caleg secara langsung. Akan tetapi pemberian uang tersebut dapat dilakukan melalui perantara orang lain termasuk keluarga, tim sukses, sahabat, dan seterusnya. Ada beberapa macam-macam bentuk pemberian uang dari calon anggota legislatif ke masyarakat yang terlibat dengan politik uang (money politics). Ada bermacam-macam sebagai berikut:

1) Melalui tim sukses caleg;

2) Melalui orang terdekat;

3) Pemberian langsung oleh ke masyarakat; dan

4) Dalam bentuk undian.

Sisi etika politik yang lainnya adalah pemberian uang kepada rakyat dengan harapan agar terpilihnya menjadi DPR, pada gilirannya menyumbat partisipasi politik. Rakyat dalam proses seperti ini tetap menjadi objek politik dari pihak yang memiliki kekuasaan.

Politik uang bukan secara moral saja yang salah dalam dimensi agama juga tidak dibenarkan, sebab memiliki 
dampak yang sangat berbahaya untuk kepentingan bangsa ini. Jika yang dihasilkan adalah kekecewaan rakyat, maka sesungguhnya yang akan mengadili adalah rakyat itu sendiri. Makin maraknya money politics Masyarakat semakin terbiasa dengan praktik politik uang dengan dilaksanakannya pemilihan umum secara langsung. Dalam Pemilu legislatif tahun 2014, politik uang menjadi semakin tak terkendali. Sebab banyak calon anggota DPR yang berkompetisi untuk memperebutkan dukungan rakyat. Karakter rakyat yang kian pragmatis akan dilihat oleh para politikus sebagai peluang untuk memenangkan kompetisi dengan cara menyebar uang dengan sebutan politik uang (money politics). Untuk melawan praktik politik uang, diperlukan para politikus sejati yang benar-benar memahami kepentingan rakyat bahwa pengertian politik adalah seni menata negara dan tujuannya adalah menciptakan kebaikan bersama agar rakyat lebih sejahtera, politik memerlukan orang-orang baik, memiliki keunggulan komparatif dalam arti memiliki kompetensi, dan sekaligus juga memiliki keunggulan kompetitif. Sebab, kebaikan dalam politik perlu diperjuangkan sampai ia tertransformasi ke dalam kebijakan-kebijakan politik negara.

\section{b. Mekanisme Penyelesaian}

\section{Pelanggaran Pidana Pemilu}

Proses penyidikan. Sebenarnya penanganan tindak pidana Pemilu tidak berbeda dengan penanganan tindak pidana pada umumnya melalui Panwaslu, kepolisian kepada kejaksaan dan ke pengadilan. Secara umum perbuatan tindak pidana yang diatur dalam UU Pemilu juga terdapat dalam KUHP. Tata cara penyelesaian juga mengacu kepada KUHAP. Dengan asas lex specialist derogat generalis maka aturan dalam UU Pemilu lebih utama. Apabila terdapat aturan yang sama maka ketentuan yang diatur KUHP dan KUHAP menjadi tidak berlaku.

Mengacu kepada Pasal 249 angka (5) UU Pemilu, temuan dan laporan tentang dugaan pelanggaran Pemilu yang mengandung unsur pidana, setelah dilakukan kajian dan didukung dengan data permulaan yang cukup, diteruskan oleh Bawaslu kepada penyidik kepolisian. Proses penyidikan dilakukan oleh penyidik Polri dalam jangka waktu selama-lamanya 14 hari tersebut termasuk hari libur. Hal ini mengacu kepada KUHAP yang mengartikan hari 
adalah 1 x 24 jam dan 1 bulan adalah 30 hari.

Guna mengatasi kendala waktu dan kesulitan penanganan pada hari libur, pihak kepolisian telah membentuk tim kerja yang akan menangani tindak pidana Pemilu. Setiap tim beranggotakan antara 4-5 orang. Tim Penyidik Tindak Pidana Pemilu Polri Bareskrim: 7 Tim (4 dalam negeri +3 luar negeri), Polda: 5 Tim, Polwil: 3 Tim, Polres: 10 Tim. Dengan adanya tim kerja tersebut maka penyidikan akan dilakukan bersamasama. Setelah menerima laporan pelanggaran dari Bawaslu, penyidik segera melakukan penelitian terhadap:

1) Kelengkapan administrasi laporan yang meliputi: keabsahan laporan (format, stempel, tanggal, penomoran, penanda tangan, cap/ stempel), kompetensi Bawaslu terhadap jenis pelanggaran, dan kejelasan penulisan; dan materi/ laporan yang antara lain: kejelasan identitas (nama dan alamat) pelapor, saksi dan tersangka, tempat kejadian perkara, uraian kejadian/ pelanggaran, waktu laporan.

2) Berdasarkan identitas tersebut, penyidik melakukan pemanggilan terhadap saksi dalam waktu 3 hari dengan kemungkinan untuk memeriksa saksi sebelum 3 hari tersebut yang dapat dilakukan ditempat tinggal saksi. 14 hari sejak diterimanya laporan dari Bawaslu, pihak penyidik harus menyampaikan hasil penyidikan beserta berkas perkara kepada penuntut umum (PU).

3) Batas Waktu Penanganan Pelanggaran Pemilu Bawaslu memiliki waktu selama 3 hari untuk melakukan kajian atas laporan atau temuan terjadinya pelanggaran. Apabila Bawaslu menganggap laporan belum cukup lengkap dan memerlukan informasi tambahan, maka Bawaslu dapat meminta keterangan kepada pelapor dengan perpanjangan waktu selama 5 hari.

\section{PENUTUP}

\section{A. Kesimpulan}

Penegakan hukum terhadap tindak pidana politik uang pada masa kampanye yang memenuhi aspek hukum adalah setiap pelaksana kampanye Pemilu yang dengan sengaja menjanjikan atau memberikan uang atau materi lainnya sebagai imbalan kepada peserta kampanye Pemilu secara langsung ataupun tidak langsung. Ada beberapa faktor penyebab pelanggaran pidana 
Pemilu karena; pertama, kurangnya

kejaksaan dalam pelaksanaan pengawasan tidak profesional dalam penegak hukum pada saat pelaksanaan kampanye mengakibatkan politik uang dimana-mana; kedua, koordinasi antara pengawas Pemilu dengan kepolisian belum berjalan dengan baik; ketiga, perlunya penegakan hukum yang lebih baik, memberikan kesadaran pendidikan politik pada calon legislatif agar tidak menggunakan politik uang, maka perlunya peran penegak hukum berani, jujur, adil, serta profesional untuk menegakkan hukum agar demokrasi berjalan dengan baik sebagai wujud kedaulatan rakyat.

Bentuk perbuatan yang dapat dikualifikasi sebagai tindak pidana politik uang pada masa kampanye, Perbuatan yang melanggar tindak pidana Pemilu bermacam-macam modus pelanggaran dengan cara membagibagikan uang tunai secara langsung, membagikan barang seperti sembako yang berisi beras, mie, minyak sayur, gula telur, dan lain-lain; memberikan dana bantuan dan menjanjikan sesuatu secara kelompok maupun individu. Maka perlunya kepastian dan penegakan hukum bahwa hukum itu ada dan berjalan, perlunya koordinasi penegak hukum antara, Panwaslu, Kepolisian dan

sanksi pidana terhadap pelanggar politik uang agar membuat efek jera terhadap pelaku. Untuk terselenggaranya Pemilu yang demokratis sebagai kedaulatan rakyat dan menghasilkan wakil rakyat yang memiliki integritas yang dipercaya oleh rakyat.

\section{B. Saran}

Dalam penegakan hukum terhadap tindak pidana Pemilu pada masa kampanye Panwaslu harus memiliki keberanian dan kejujuran secara profesional untuk melakukan tindakan penegakan hukum bagi calon anggota legislatif yang menggunakan pelanggaran politik uang untuk tercapainya penegakan hukum, terselenggaranya Pemilu yang demokratis. Sehubungan dengan permasalahan tersebut. Sebagai berikut. Pertama perlunya penegasan sanksi pidana dalam undang-undang ini khususnya bagi penegakan hukum yang menyangkut tindak pidana politik uang, karena sanksi pidana pada yang memberi dan menerima tidak dipisahkan (kumulatif). Banyak calon anggota legislatif peserta Pemilu melakukan pelanggaran Pemilu politik uang dalam undang-undang. Undang-undang ini 
perlu direvisi dalam hal sanksi pidana pelanggaran dari tindak pidana yang antara pemberi dan penerima, minimal terjadi di Kabupaten Serang Provinsi dan maksimum, waktu yang sangat Banten (18 kasus Pelanggaran Pemilu). pendek dalam proses hukum perlu Tidak ada yang sampai diproses ke ditinjau kembali. Kedua dalam tingkat pengadilan, hanya sanksi penerapan undang-undang ini fungsi administrasi dengan alasan tidak cukup penegakan hukum harus tegas dilakukan, bukti. Panwaslu, kepolisian dan oleh aparat yang ditunjuk dalam undang- kejaksaan harus sungguh-sungguh dalam undang ini, baik Banwaslu/Panwaslu, penyelesaian pelanggaran tindak pidana polisi, dan kejaksaan. Karena bukti Pemilu. 


\section{DAFTAR PUSTAKA}

\section{A. Buku}

Barda Nawawi Arief, Bunga Rampai Kebijakan Hukum Pidana, Citra Aditya Bakti, Bandung, 1996.

Bernard Arief Sidharta, Refleksi Tentang Struktur Ilmu Hukum, Mandar Maju, Bandung, 1999.

Dellyana Shant, Konsep Penegakan Hukum, Liberty, Yogyakarta, 1988.

DidiNazmi Yunus, Konsepsi Negara Hukum, Angkasa Raya, Padang, 1992.

DidiNazmi Yunus, Konsepsi Negara Hukum, Angkasa Raya, Padang, 1992.

Djoko Prakoso, Tindak Pidana Pemilihan Umum, Bina Aksara, Jakarta, 1987.

Elydar Chaidir, Negara Hukum, Demokrasi dan Konstalasi Ketatanegaraan Indonesia, Kreasi Total Media, Yogyakarta.

Jimly Asshiddiqie, Konstitusi dan Konstitusionalisme Indonesia, Sinar Grafika, Jakarta, 2011.

Kansil, Pengantar Ilmu Hukum dan Tata Hukum Indonesia, Balai Pustaka, Jakarta, 1989.

Hukum Tata Negara Republik Indonesia, Bina Aksara, Jakarta, 1986.
—. Sistem Pemerintahan Indonesia, Bumi Aksara, Jakarta, 2008.

M. Rusli Karim, Pemilihan Umum Demokratis Kompetitif, Cet I. Tiara Wacana, Yogyakarta, 1991.

Miriam Budiarjo, Dasar-dasar Ilmu Politik, Cetakan ketujuh belas. Gramedia Pustaka Utama, Jakarta, 1996.

Moeljatno, Asas-Asas Hukum Pidana. Rineka Cipta, Jakarta, 2002.

Moeljatno. Asas-Asas Hukum Pidana, Rineka Cipta. Jakarta, 2002.

Moh Kusnadi, Harmally Ibrahim. Pengantar Hukum Tata Negara Indonesia. Sinar Bakti, Jakarta, 1988.

Morissan, Hukum Tata Negara RI Era Reformasi, Ramidan Perkasa, Jakarta, 2005.

Muhammad Tahir Azhary, Negara Hukum, Prenada Media, Jakarta, 2004.

Muladi, Hak Asasi Manusia, Refika Aditama, Bandung, 2009.

Munir Fuady, Teori Negara Hukum Modern (Rechtstaat). Refika Aditama, Bandung, 2009. 
Rozali Abdullah, Mewujudkan Pemilu yang Lebih Berkualitas (Pemilu Legislatif). Raja Grafindo Persada, Jakarta, 2009.

Sintong Silaban, Tidak Pidana Pemilu Suatu Tinjauan Dalam Rangka Mewujudkan Pelaksanaan Pemilu Yang Jujur Dan Adil, Sinar Harapan, Jakarta, 1997.

Soerjono Soekanto. Sosiologi Suatu Pengantar. Raja Grafindo, Jakarta, 2010.

Faktor-Faktor Yang Mempengaruhi Penegakan Hukum Cetakan Kelima, Raja Grafindo Persada, Jakarta, 2004.

\section{B. Peraturan Perundang-Undangan}

Undang-Undang Dasar Negara Republik Indonesia tahun 1945;

Undang-Undang Nomor 1 Tahun 1946 tentang Peraturan Hukum Pidana;

Undang-Undang Nomor 8 Tahun 1981 tentang Hukum Acara Pidana;

Undang-Undang Republik Indonesia Nomor 24 Tahun 2003 Tentang Mahkamah Konstitusi;

Undang-Undang Nomor 2 Tahun 2008 tentang Partai politik;

Undang-Undang Nomor 2 Tahun 2011 tentang Perubahan UndangUndang 2 Tahun 2008 tentang Partai Politik;

Undang-Undang Republik Indonesia Nomor 15 Tahun 2011 tentang Penyelenggara Pemilihan Umum;
Undang-Undang Nomor 8 Tahun 2012 tentang Pemilihan Umum Anggota DPR, DPD dan DPRD.

\section{Jurnal, Artikel, Makalah, Majalah, Koran, Internet, dan Lain-lain.}

Atma Suganda. Norma Dan Penegakan Hukum Tindak Pidana Politik Uang (money politics) Dalam Pemilihan Kepala Daerah. Jurnal Wacana Paraarta, 2010.

Barda Nawawi Arief dalam Basuki, Jurnal Dinamika Hukum Vol. 10 No. 2, Mei 2010.

Bawaslu RI. Panduan Pengawas Pemilu Lapangan Pemilu Anggota DPR, DPD dan DPRD tahun 2014. Jakarta, 2014.

Data Pelanggaran Pemilu. Diperoleh dari Panitia Pengawas Pemilu Kabupaten Serang, 5 Mei 2015.

Harian. Radar Banten. Kamis, 22 Mei 2014.

http://budisansblog.blogspot.com/2014/0 4/memidana-pelaku-politikuang.html. Diakses Minggu, 10 Mei 2015 Pukul 07.15 WIB.

http://dunibembi. blogspot.com.kampanye-Pemilu2014 diakses tgl 21/5/2015 Pukul 06.11. WIB.

http://lannylameanda.Blogspot.com.defi nisi-jenis-jenis-dan-perbedaan diakses tgl 25/5/2015 Pukul 06.50. WIB. 
Rukmana Amanwinata. "Pengatur dan Batas Implementasi Kemerdekaan Berserikat dan Berkumpul Pasal 28 UUD 1945," Disertasi. Bandung: Fakultas Hukum Pascasarjana Universitas Padjadjaran, 1996.
www.jimly.com/makalah/namafile/56/Pe negakan. Hukum. Diakses, hari Kamis, 07 Mei 2015, Pukul. 08. 02 WIB. 